第 27 回年次大会予稿

\title{
理科授業のための科学絵本の選択を支援する件名標目付与 方法の分析 \\ An Analysis of Subject Headings Useful for Children's Science Picture Book Selection for Science Lessons
}

\author{
斎藤陽子 ${ }^{1}$ \\ Yoko SAITO ${ }^{1}$
}

1 清泉女子大学

Seisen University

干141-8642 東京都品川区東五反田3-16-21

E-mail: ysaito@seisen-u.ac.jp

理科授業の目的にあった科学絵本の選択を支援するような, 件名標目付与の方法について知見 を得ることを目的とし, 米国の小学校の授業で使用されている英語の科学絵本, 及び日本の科学絵 本を分析対象として, LC, NDL, TRCにおける件名の付与状況を調査し, 質的分析を行った.

LCCでは, フィクションや伝記にも科学概念を表す件名が付与され, 科学概念の付与のあり方も理 科学習に適した図書の選択への配慮がなされていること, 科学の探究活動に伴う感情も件名付与の 対象としていることなどが明らかになった。

キーワード: 科学絵本, 件名標目, 理科授業, 小学校

Keyword: Science Picture Books, Subject Headings, Science, Elementary Schools

\section{1 はじめに}

本研究において, 科学絵本とは, 科学概 念の獲得や科学に対する興味を高める可 能性をもつた絵本をさすものとし, 知識の 本と物語の本の両方を含むものと捉える.

科学絵本は, 理科への興味を起こさせ, 学習の見通しや理解の深まり, 振り返りに 役立つとされる $[1]$. また, 探究を続ける 科学者を描いた読夕物は, 科学コミュニケ ーションのための語彙や表現の獲得, 平成 28 年の中央教育審議会の答申 [2]において
育成すべき資質・能力とされた「学びに向 から力」や「思考力・判断力・表現力」の 育成にも貢献できるものと考えられる.

そこで, 本稿では, 授業の学習目的にあ つた科学絵本の選択を支援するような, 件名 標目付与の手法について知見を得ることを目 的とし, 英語と日本語の科学絵本に付与され た件名の比較を通して, 科学絵本の内容が件 名によってどのように表現されているのかを明 らかにしていきたい。 


\section{2 方法}

\section{1 対象資料}

次の資料に掲載された科学絵本に付与 された件名標目について分析を行った.

(1) "Picture-Perfect STEM Lessons, 3-5: Using Children's Books to Inspire STEM Learning”[3]に掲載された英 語の科学絵本, 30 点

(2)「かがくが好きになる絵本100」[4]に掲 載された英語から翻訳された科学絵 本，及びその原著作，各13点

(1)の資料は，米国の科学教育団体である 全米科学教師協会（National Science

Teachers Association，以下NSTA）から 刊行されているもので, 小学校の理科授業 の単元で活用することを想定した科学絵 本が選定されている.

(2)の資料には，科学の本の読み聞かせの 会「ほんとほんと」が，科学館や図書館， 小学校等で科学絵本の読み聞かせとその 科学絵本の内容に関連する実験や観察な どを組み合わせた活動で取り上げた科学 絵本が選定されている.

\section{2 分析方法}

対象資料の各図書に付与されている件 名を抽出し，質的分析を中心に分析した。

分析に用いる件名は, 日本語の科学絵本 については，国立国会図書館オンライン， 及びTRCが提供するTOOLiで検索された 書誌情報の件名（以下，それぞれNDL件名， TRC件名と略記）を抽出した。TRCの件名 については, 学習件名が付与されている場 合には，これも含めた。

英語の科学絵本については, 米国議会図 書館目録（The LC Catalog： 以下LCC）
で検索されたMARCレコードのLCSHによ る件名と児童件名 (Children's Subject

Headings）を抽出した。児童件名は，通常 のLCSHによる件名とは別に，米国議会図 書館の児童資料部門が管理する児童件名 標目（Children's Subject Headings）によ り付与するものである.

抽出した件名は, 翻訳のある科学絵本に ついては, 日本語の科学絵本に付与された NDLとTRCの件名と, 原作の英語の科学絵 本に付与されたLCCの件名とを比較し，そ の特徴を分析した。

翻訳書のない科学絵本については, 物語 の本（フィクションと民話）, 伝記, 知識 の本にカテゴリ分けし，各カテゴリの図書 に付与される件名の特徵を分析した.

\section{3 結果}

\section{1 件名付与状況}

対象とした科学絵本への件名付与状況 は以下の表1〜3の通りである：LCCでは， すべての科学絵本に件名が与えられ，かつ それらには科学概念を表す件名が含まれ ていた。一方，NDLやTRCでは，件名付与 のないものがあった。 NDLやTRCでは，知 識の本や伝記のカテゴリにはいる科学絵 本については件名付与されていたが, フィ クションに付与されていない。 民話は，調 查対象に1点のみであったが，この例では， NDLでは形式件名（民話）が付与されてお り，TRCでは件名付与がなかった。

表1 NDLにおける件名の付与状況 対象 科学絵本 資料 点数 3 13 付与あり 付与なし

$\begin{array}{ll}2 & 1 \\ 8 & 5\end{array}$


表2 TRCにおける件名の付与状況

対象 科学絵本 資料 点数

(1) 3

(2)

13

付与あり 付与なし

$\begin{array}{ll}2 & 1 \\ 8 & 5\end{array}$

表3 LCCにおける件名の付与状況 対象 科学絵本 資料 点数

\begin{tabular}{l|lll} 
(1) & 30 & 30 & 0 \\
(2) & 13 & 13 & 0
\end{tabular}

各科学絵本に対する件名の付与数は, LCCでは3個以上与えられている例が多く 見られたのに対し，NDLやTRCでは，1個 ないし2個の付与であった。

\section{2 フィクションへの件名付与}

NDLやTRCでは，フィクションの場合は 件名付与されていないが，LCCでは付与さ れていた. LCCでも, 一般のLCSHの付与 の方針では，フィクションへの件名付与は されていないが，児童資料については，物 語の本に子どもたちに情報を与えるよう な内容が扱われている場合には，細目 一Fiction を付加した件名を付与している. 抽象的概念, 感情を表す概念についても件 名が付与されている[5].

調査した科学絵本では, たとえば次のよ うな件名が付与されていた。

\section{Seeds--Fiction.}

Trees--Fiction.

Patience--Fiction.

Failure (Psychology)--Fiction.

Perseverance (Ethics)--Fiction.

感情を表す概念の件名が付与されてい る科学絵本には, 必ず, 科学概念を表す件
名も付与されている. 感情を表す概念は, その科学絵本の中で扱われている科学概 念と独立して扱われているものではなく， その科学概念の探究に付随して表れる, 科 学の探究を行おうとする子どもたちも直 面することになるであろう感情が表現さ れていると捉えられるものであった.

\section{3 科学概念の付与}

科学概念については, LCCでは, 物語の 本, 伝記, 知識の本のすべてのカテゴリの 科学絵本に付与されていた. NDLやTRCで は，物語の本や伝記には付与されていなか った. LCCでは，科学概念に関して，(1)学 問領域を示す件名が付与されていたこと， (2)事象だけでなく, 科学概念を表す件名が 付与されていたこと，(3)形式細目を使用し て，取り扱い方を表現していたこと，児童 件名標目では子どもに適した用語を使用

していたこと，などが読みとれた。

(1) 学問領域の付与例

「山」だけではなく，「地質学」という 学問領域を併せて付与することで，「山」 がどのような観点から扱われているかが 理解できるようになっていた。

\section{Mountains.}

\section{Geology.}

（2）科学概念を表現する付与例

丸括弧や細目を使用して，対象とした事 物だけでなく，そこで扱われている概念を 明示する件名が付与されていた。たとえば，

「楓」という事象について，「成長」とい う科学概念が付与されていた。

\section{Springs (Mechanism)}

Maple-Growth 
（3）形式細目による取り扱い方表現例 形式細目を使用して，「実験」といった 科学概念の取り扱い方が表現されていた.

Chemistry -- Experiments

Dogs--Anecdotes

\section{1 伝記への件名付与}

NDLやTRCでは，個人の伝記については， 人名の典拠形が付与されていた. LCCでは, 人名の典拠形だけでなく, 被伝者の職業, 専門分野, 国名や民族名などが併せて付与 されていた。 また, 被伝者が女性である場 合には，下のように女性であることを明示 した件名も併せて付与されていた。

Cartographers--United States--Biography.

Women cartographers--United States

--Biography.

\section{4 考察}

科学絵本について, LCC, 及びNDL, TRC における件名付与の状況を比較調査した 結果明らかになってきた，LCCでは，事象 だけではなく科学概念や学問領域を示す 件名を付与していること, 科学概念ととも に感情を表す概念について件名付与して いること，科学概念を表す件名をフィクシ ヨンへ付与することの意義について若干 の考察を加えてみたい.

事象だけではなく, 科学概念に対する件 名を付与することは, 理科学習を支援する 上で重要な要素であると考える. 理科学習 において, 事象は, 科学概念を学習するた めの例として取り上げられる. 事象の中に ある概念を読夕取り, 理解する力を身に付 けることが，理科学習の目標であると捉え られるからである。事象だけでは, 図書と
学習目的との適合性の判断ができない.

科学の探究は自然を見つめることであ るが，その探究の成果は言語コミュニケー ションによって共有され, 深められていく. 物語によって科学の概念や言葉が子ども たちの心に感動を与え, 深くとどまり, 探 究の過程で起こる困難を乗り越え, 学習に 向かう力を高めてくれる. 感情概念件名の 付与や，フィクションへの科学概念件名の 付与は，こうした要素をもった本の選択の 手がかりを与えるものと考える。

\section{4 おわりに}

日本語と英語の科学絵本への件名の付 与状況を, LCCとNDL, TRCについて調べ, 件名付与の特徽を分析した.今後さらに科 学絵本の内容を精査しながら, 件名標目付 与のあり方について検討していきたい.

\section{参考文献}

[1]仲井勝巳：「小学校理科・生活科にお ける科学絵本の研究」日本理科教育学会 全国大会要項 , No. 65, p. 249, 2015. [2]中央教育審議会：「幼稚園, 小学校, 中学校, 高等学校及び特別支援学校の学習 指導要領等の改善及び必要な方策等につ いて（答申）」平成28年12月21日.

[3] Morgan, Emily and Ansberry, Karen. Picture-Perfect STEM Lessons, 3-5: Using Children's Books to Inspire STEM Learning. NSTA Press, 2017, 389p. [4]科学の本の読み聞かせの会「ほんとほん と」：「かがくが好きになる絵本 $100 」$, 幻冬 舎, $127 \mathrm{p} ., 2015$.

[5] "Library of Congress Subject Headings" $33^{\text {rd }}$ ed. , Library of Congress, 1150p, 2011. 